TOMASZ DERLATKA

Instytut Slawistyki Czeskiej Akademii Nauk, Praga

\title{
Z PRZEWODNIKA PO POWIEŚCI SŁOWIAN ZACHODNICH (1945-1995)
}

Prezentowane opracowanie zawiera wybór haseł z przygotowywanego Przewodnika po powieści Stowian Zachodnich (tytuł roboczy). Przewodnik adresowany jest w pierwszym rzędzie do podejmujących badania o charakterze komparatystycznym nad literaturami Słowian Zachodnich i obejmować będzie okres pięćdziesięciu lat istnienia, funkcjonowania i przemian powieści autorów zachodniosłowiańskich (1945-1995): kaszubskich, polskich, słowackich (ze Słowacji oraz tzw. Dolnej Ziemi), czeskich oraz górno- i dolnołużyckich. Poszczególne hasła przedstawiać będą najważniejsze (zdaniem autora) utwory, na obecnym etapie pracy nie sposób jeszcze określić ich dokładnej liczby. Budowa hasła składać się będzie z krótkiej prezentacji treści danej powieści, informacji bibliograficznej (kolejne wydania, ew. przekłady, przy czym recepcja w innych językach ograniczona zostanie wyłącznie do areału zachodniosłowiańskiego), interpretacji, znaczenia utworu dla całokształtu twórczości konkretnego pisarza, konkretnej literatury narodowej, wreszcie - powieściopisarstwa Słowian Zachodnich jako całości, wyboru (maksymalnie pięć pozycji) najważniejszej literatury przedmiotu. W Przewodniku, prócz utworów spełniających konwencjonalne parametry powieściowości, uwzględnione zostaną w uzasadnionych przypadkach mikropowieści i formy zbliżone. Postępowanie takie jest uprawnione szczególnie w odniesieniu do „mniejszych” literatur zachodniosłowiańskich: górno-, dolnołużyckiej, kaszubskiej oraz twórczości wojwodińskich Słowaków, których specyficzny rozwój, zależny od technicznych możliwości publikowania tekstów literackich, nie pozwolił na pełne wykształcenie powieści, najobszerniejszego z gatunków literackich.

Zastosowane w hasłach skróty niestandardowe:

cz. $=$ czeski [i formy odmienne $]$

dłuż. $=$ dolnołużycki [i formy odmienne]

głuż. = górnołużycki [i formy odmienne]

hist. = historyczny [i formy odmienne]

j. $=$ język [i formy odmienne]

kasz. $=$ kaszubski [i formy odmienne $]$ 


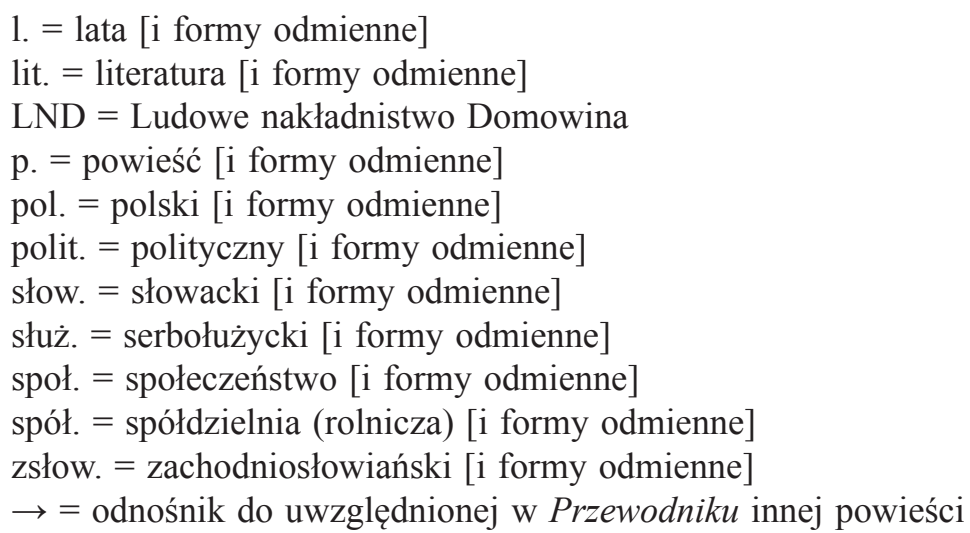

\section{BJERO, Wylem [1902-1988]}

\section{Wjaska pod golu (Budyšyn: Domowina 1959)}

Podtytuł Wulicowańko z našogo casa, określa utwór dłuż. autora, tłumacza, redaktora („Nowy Casnik”, „Serbska Pratyja”), jako opowiadanie [dłuż. „wulicowańko”]; z uwagi na próbę oddania wydarzeń w możliwie szerokim epickim zakresie, utwór uważać można również za mikropowieść. Należąca do odmiany p. produkcyjnej w wariancie wiejskim, tj. o zakładaniu i funkcjonowaniu spół. produkcyjnej, stanowi pierwszy utwór o takiej tematyce w lit. łuż.

Przedstawione $\mathrm{w}$ utworze zdarzenia rozgrywają się w położonej pod lasem wsi Podgola, której opisem narrator rozpoczyna relację. Przedstawia kolejno historię wsi oraz aktantów - najbogatszego we wsi gospodarza Zobaka, jego córkę Leńkę, rodziny Nowaków (Nowakojc) oraz Cechów. Z Nowakami spotykamy się przy kolacji; syn Fryco wykłada rodzicom na przykładzie sąsiedniej wsi Starice zalety kolektywnej gospodarski; ojciec zdradza, iż o idei spół. rozmyśla od dłuższego czasu, proponuje także zasięgnąć rady u najlepszego gospodarza w Podgoli, Cechowego Měta. Spotkanie ma miejsce w niedzielę, w dyskusji padają argumenty pro i kontra spół., do idei gorąco przekonuje starych gospodarzy młodzież (Marjana i Gerat). Rozmowy o możliwym założeniu spół. w Podgoli toczą się również przy pracach polowych. W środowy wieczór w miejscowej gospodzie spotyka się grupa mieszkańców wsi, która spotykała się w tym samym gronie w czasie rządów narodowych socjalistów; to przeciwnicy socjalizmu i gorący zwolennicy Zachodu, do których należy również karczmarz. Zobak, Šaparjowy Awgust, Rizo, Mjeńk oraz karczmarz wiedzą już, że postępowi gospodarze planują założyć we wsi spół.; opracowują plan obrony, zakładający działania o charakterze sabotażowym. W tym samym czasie w domu Nowaków ma miejsce spotkanie aktywistów; głównym problemem staje się wybór odpowiedniego dla biednej wsi typu spół. [I, II, III], ostatecznie decydują, iż na początek najodpowiedniejszy będzie typ I; ktoś (Šapar za pieniądze Zobaka) wybija kamieniem okno. Następnego dnia we wsi panuje poruszenie z powodu incydentu z kamieniem oraz szerzonych przez największą plotkarę, Šaparjową, informacji o możliwych podpaleniach; Šaparjowa informuje Zobaka, że jego córka, Leńka, ma się ku przystojnemu synowi stare- 
go Nowaka, Frycowi. Funkcjonariusze Domowiny [organizacja polit. Serbołużyczan] składają wizytę Cechowi, po czym wspólnie ruszają agitować nieprzekonanych gospodarzy; pomimo sceptycyzmu miejscowych, okazuje się że „miejscy” funkcjonariusze znają się na robocie w polu nie gorzej niż gospodarze. Wieczorem w gospodzie odbywa się spotkanie informacyjne, na którym Cech przedstawia ideę i zalety spół.; głos zabierają kolejni gospodarze, jedni popierają plan uspółdzielczenia wsi, inni są przeciw; najbardziej postępowi, m.in. Fryco, podpisują akt dobrowolnego przystąpienia. W Podgoli nastaje nowy czas. Zobak nakazuje przerwać wszelkie akty nieprzyjaźni wobec „socjalistów”; karci Leńkę za kontakty z Frycem, w wyniku czego odchodzi ona z Frycem do Nowaków, następnie podejmuje pracę w spółdzielczym kurniku w Staricach. Przychodzi czas żniw, pola wolnych gospodarzy są obrobione, natomiast spółdzielcze nietknięte, co daje okazję do drwin; adwersarzom rzedną miny, kiedy spółdzielczy kombajn w rekordowym tempie kosi pola, co wywiera wielkie wrażenie na niezrzeszonych gospodarzach. Nadciągają burze, z całej wsi jedynie zboże spół. znajduje się bezpieczne pod dachem, inni gospodarze ponoszą duże straty; liczba chętnych do wstąpienia do spół. wzrasta lawinowo. Cecha i Nowaka niepokoi obojętność Zobaka; to jednak tylko pozory, po kolejnym spotkaniu spółdzielców, Zobak nakazuje przystąpić do realizacji planu; karczmarz się wycofuje. Zobak uświadamia sobie, że bez pomocy Leńki nie da sobie rady z gospodarstwem, jedzie do Staric, po drodze doświadczonego gospodarza zachwycają sukcesy tamtejszej spół.; Leńka odmawia jednak powrotu do domu. Rozeźlony Zobak udaje się do Riza i przekonuje go do podjęcia ustalonych kroków, jednak Rizo, podobnie jak wcześniej karczmarz, wycofuje się ze współpracy. Zadania podejmuje się natomiast pijaczyna Mjeńk, z tym, że jako pierwsza spłonąć ma nie stodoła Cechów, lecz Nowaków, co ma być rodzajem zemsty na Frycu za „uprowadzenie” Leńki. By nie zostać posądzonym o współudział, Zobak wyjeżdża do Berlina, następnie przekracza granicę i udaje się w głąb Niemiec Zachodnich. Fryco przeczuwając niebezpieczeństwo, ostrzega innych, sam unieszkodliwia w ostatniej chwili Mjeńka i zgodnie z prawem przejmuje gospodarstwo uciekiniera-Zobaka, jego prawa spadkobierczyni, Leńka, zgłasza dobrowolny akces do spół. Mija kilka tygodni. Šapar zwraca Nowakowi pieniądze za wybitą szybę w oknie; Mudra pragnie przystąpić do spół., do której, wraz z Leńką, zostaje przyjęty na kolejnym spotkaniu. Rozwijająca się oraz przynosząca zyski spół. w Podgoli przechodzi na typ III; właściwe dla tego typu otwarte i zautomatyzowane stodoły ulokowane zostają w części gospodarstwa Zobaka. Karczmarz i Rizo rozmyślają o wstąpieniu do spół., następnie do niej wstępują. Mija kilka miesięcy. Wieś jest całkowicie zmieniona; jest już po ślubie Leńki i Fryca; z Zachodu, gdzie codzienne życie ma się nijak do kolportowanych przez zwolenników Adenauera rajskich obrazów, powracają w rodzinne strony straceni synowie wioski. Jedynym, który jeszcze nie wrócił, i na którego powrót czekają we wsi wszyscy z napięciem, jest Zobak, w chwili obecnej słabo opłacany najemny pracownik na Zachodzie. Pewnego dnia słyszy w radiu audycję w języku dłuż., jej bohaterem jest już w całości spółdzielcza wieś Podgola, przemawia również Leńka. Zobak nie potrafi opanować wzruszenia, skruszony wraca w rodzinne strony, gdzie zostaje przyjęty z otwartymi ramionami przez rodzinę i sąsiadów; organy władzy okazują się miłosierne, skazując Zobaka za przygotowywanie i kierowanie akcją przestępczą na wyrok w zawieszeniu. Zobak staje się aktywnym członkiem spół. i wiejskiej społeczności.

Wjaska pod golu to wysoce schematyczny utwór w poetyce socrealizmu. Uproszczona do absurdu fabuła, oczywista od samego początku teza, przesłanie oraz rozwiązanie kon- 
fliktu, żadnych prób uatrakcyjnienia schematu powodują, iż jest to dzieło o niewielkiej wartości. Zastosowane przez BJERA schematy fabularne pokrywają się z klasycznym, właściwym dla p. produkcyjnej, zestawem motywów, przy czym w kontekście bliskości obu lit. służ. zasygnalizować należy konwergencję szeregu wątków z rozwiązaniami prozaików głuż.: sabotaż u J. BRĚZANA ( $\rightarrow 52$ Wochen sind ein Jahr; $\rightarrow$ MAS), młodych przekonujących rodziców do idei spół. u tegoż $(\rightarrow$ Trix a wot Jonas) oraz u B. ŠOŁTY $(\rightarrow$ Statok bjez hospodarja). Wjaska pod golu to utwór pisany niejako na zamówienie, stanowił oczekiwaną przez decydentów dłuż. odpowiedź na nieporównywalnie liczniejsze głuż. p. produkcyjne 1. 50. i 60.; podobnie jak tamte służyć miała jako oręż propagandowy w walce o uspółdzielczenie wsi górno- i dolnołużyckich.

Niewiele do zaoferowania ma utwór również w planie formalnym. Narrator to instancja omnipotentna, forma narracji zmienna, w toku opowiadania częste fragm. w 1 os. pl., co podkreślać ma przynależność narratora i czytelnika (odbiorcy narracji) do tego samego kręgu w celu wzmocnienia tezy; w przebiegu narracji preteritalnej liczne przejścia do czasu teraźniejszego w funkcji preasens historicum. Relacja narratora funkcjonalnie podporządkowana została kwantytatywnie i względem rozwoju akcji dialogom; konsekwentnie wyizolowane $\mathrm{z}$,tekstu” narratora, uproszczone do funkcji czysto informacyjnej nie przekonują, w wielu miejscach służą bezpośredniej ideologicznej indoktrynacji czytelnika. Deskrypcje, poza opisem początkowym, mocno zredukowane. Dla sposobu prezentacji zdarzeń właściwa jest zbyt silna konsekutywność, każde zdarzenie, każdy krok postaci zostaje przez narratora wyczerpująco wyjaśniony, przez to jego relacja staje się nużąca. Jej zdynamizowaniu służyć miały sceny symultaniczne: spotkania antagonistycznych kręgów, rozmyślania nocne u Nowaków i Cechów. W planie postaci zwraca uwagę wprowadzenie szeregu figur drugoplanowych, symbolizujących rzeczywiste, występujące na Łużycach, nastawienie gospodarzy do idei kolektywnego gospodarzenia. Postaci główne pogrupowane zostały zgodnie z poetyką realnego socjalizmu w schematycznie antagonistyczne kręgi; do kręgu „wsteczników” należą Zobak, Šaparjowy Awgust, Rizo, Mjeńk, karczmarz; do kręgu postaci pozytywnych (,pioněry postupa”) Nowakowie, Cechowie, młodzież oraz nauczyciel. W utworze wyzyskał BJERO typowy dla prozy głuż. i dłuż. motyw karczmy jako przestrzeni neutralnej, w której możliwe jest bezkonfliktowe spotkanie postaci przynależnych do antagonistycznych kręgów; mikropowieść jest też jedynym utworem z zakresu lit. służ. o problemach spół. rolniczej, w której nie pojawił się leksem „kołchoz” na jej określenie.

Wjaska pod golu, druga po zbiorze opowiadań Mjazka (1958) pozycja w lit. dossier BJERA, pierwsza i jedyna jego próba powieściowa, stanowi jednocześnie pierwszą i jedyną próbę p. napisanej w j. dłuż.; z tego też faktu wypływa jej znaczenie dla całokształtu problematyki powieściowej Słowian Zachodnich. Poza Wjaska pod golu lit. dłuż. posiada bowiem nieliczne translacje całości i fragm. p. autorów głuż. (m.in. J. BRĚZANA, J. KOCHA). Niezadowalająca pozycja p. w systemie gatunków lit. dłuż. wynika z ograniczonego sposobu istnienia lit. „małych”, w których miejsce p. zajęła mikropowieść; sytuację tę potwierdzają również inne „mniejsze” lit. zsłow.: głuż., kasz. oraz lit. wojwodińskich Słowaków.

Lit. S. Wilczek, Wylem Bjero, „Poglądy” XV(1976), nr 19 [335]. 


\section{KUBAŠEC, Marja [1890-1976]}

Bosćij Serbin (Budyšin: LND; I - 1963, II - 1964, III - 1965)

Pierwsza w lit. głuż. p. hist. sensu stricto, druga po $\rightarrow$ trylogii o Feliksie Hanušu J. BRĚZANA i zarazem ostatnia głuż. trylogia.

Koncepcja p. oraz pierwsze szkice pochodzą z drugiej połowy 1. 50.; bezpośrednim impulsem, który popchnął autorkę do podjęcia próby napisania p., był niewłaściwy jej zdaniem obraz nauczycielstwa, przedstawiony przez cz. pisarza, V.K. KLICPERĘ w dramacie Potopa světa (1815/1816), który KUBAŠEC przełożyła na j. głuż. Prymarnie tytuł p. miał brzmieć Wučer (Nauczyciel); poświadczone są również inne postaci, w tym Wučerka (Nauczycielka), co wskazywać mogło na pierwotny zamiar ustanowienia protagonistą p. postaci kobiecej [KUBAŠEC była pierwszą głuż. studentką i nauczycielką; los i wybory bohatera p. można odnosić do sytuacji autorki]; wstępnie planowana na jeden tom. Dwa fragmenty w periodykach rodzimych; (jedyna) translacja na j. cz. jako Kantor Serbin (tłum. J. MUDRA, V. STRAKOVÁ, L. ŠATAVA, 1986). Wielki sukces czytelniczy, największy bestseller powieściowy w na obszarze głuż.; tom pierwszy doczekał się drugiego wydania w 1964 r.; drugi i trzeci ukazały się w podwójnym nakładzie; wszystkie wyprzedane do ostatniego egzemplarza; trylogia o Bosćiju Serbinie była w rodzimym kręgu czytelniczym popularniejsza niż BRĚZANOWSKA $\rightarrow$ trylogia o Feliksie Hanušu. W 1966 r. przyznano autorce za trylogię nagrodę literacką organizacji Domowina pierwszej klasy.

Tom pierwszy rozpoczyna scena pogrzebu mieszczanina Žemra, donatora wiejskich szkół pokątnych. W jednej z nich, we wsi Ćemjercy [wł. Ćěmjercy] naucza stary pedagog Donat. Ciężka choroba powoduje, iż zastępuje go młody, zaangażowany, acz niewykształcony, nauczyciel, po profesji szewc, Bosćij Serbin. Ubogiemu Bosćijowi zdaje się sprzyjać los, gdyż uczuciem pała doń córka najbogatszego gospodarza, starego Krala, Jěwa. Na miłość obojga nieprzychylnym wzrokiem spogląda matka dziewczyny, pragnąca wydać ją za Jakuba Nuka, jedynego spadkobiercę sąsiedzkiego, równie zamożnego gospodarstwa. Kral przeciwnie, jest gotów pobłogosławić małżeństwu, pod warunkiem, że Bosćij dostanie się do cechu szewców miejskich, w czym jest w stanie mu pomóc. W ten sposób bohater postawiony zostaje przed trudnym wyborem: między miłością do kobiety a pasją dydaktyczną. W miarę upływu czasu Bosćij zdaje sobie sprawę z niedostatków własnego wykształcenia; szczególnie wyraźnie dostrzega to, przyrównując się do przyjaciela, Handrija, studenta ewangelickiego uniwersytetu. Przyjaźn i dyskusje z Handrijem powodują, iż Bosćij podejmuje intensywne samodokształcanie, w czym najbardziej przeszkadza mu brak podręczników; korzystnym zbiegiem okoliczności, ma okazję wyprawy do Pragi z transportem produktów rolniczych z pobliskiego klasztoru; decyzja o wyjeździe powoduje niezadowolenie Jěwy, umiejętnie podsycane intrygami matki. Po męczącej podróży Bosćij wraz z przyjaciółmi docierają do Pragi; jednym z wielu wydarzeń, jakie dane mu było przeżyć w stolicy Czech, było przekazanie mu przez pedagoga Lindę zagrożonych zniszczeniem książek J.A. KOMENSKIEGO (Dydaktyka). W trakcie przechadzek po Pradze, dokonuje się w Bościju, jak się zdaje, zasadniczy przełom: już wie, kim chciałby zostać, ma też najlepsze materiały do dalszej nauki... 
Akcja tomu drugiego trwa od powrotu Bosćija z Pragi na Łużyce (1757) do końca 1758. Bohater dowiaduje się, że Jěwa przeniesie się do budziszyńskiej kolegiaty, gdzie będzie przygotowywać się do roli gospodyni i małżonki. W tym samym czasie dotychczasowy zarządca dóbr kolegiaty rezygnuje z pracy. Stary Kral proponuje Bosćijowi zastępstwo. Po raz kolejny bohater postawiony zostaje przed alternatywą: miłość i finansowa prosperita lub nauczycielstwo i bieda. Miłość młodych rozkwita, tymczasem w wiejskiej szkole piętrzą się problemy; sytuację komplikuje jeszcze śmierć Donata. Przed ostatecznym rozstrzygnięciem ratuje Bosćija decyzja zarządcy o przedłużeniu zatrudnienia o rok; traf ten bohater przyjmuje z ulgą, aczkolwiek wystawia w ten sposób związek z Jěwą na próbę. Jak się zdaje, nie to będzie dla obojga zagrożeniem największym. W zakątków całego kraju dobiegają wieści o grożącej wojnie w imię wiary... Część druga p. kończy się wkroczeniem wojsk Fryderyka II Wielkiego do Budziszyna.

Ostatnią część cyklu rozpoczyna nakreślenie ogólnej sytuacji Łużyc w czasie wojny. Ogrom danin przytłacza zarówno mieszczan, jak i wieśniaków; nieprzyjacielskie wojska rozpoczynają branki wśród miejscowej ludności. Zawierucha wojenna daje asumpt do wyrównania porachunków, Jakub Nuk denuncjuje Bosćija, który po krótkiej ucieczce w góry, zostaje schwytany w Budziszynie i wcielony do wojska pruskiego; wraz z nim w jednostce znajduje się brat Jěwy, Pětr. Od tej pory Bosćij czuwać będzie nad bratem ukochanej, jedynym spadkobiercą majątku Kralów i - być może - przyszłym szwagrem. Po udziale w wielu bitwach, obaj dezerterują po krwawej potyczce pod Kolínem, docierają do Pragi, w której spotykają się z cz. przyjaciółmi, i już jako żołnierze sascy powracają na Łużyce. Pětr ginie w bitwie pod Bukecami [1758]. Fakt ten pieczętuje los Bosćija i Jěwy: ona wyjdzie za Tomaša Wjacsławka, dziedzica bogatego majątku z okolicy, on natomiast będzie dalej nauczać, w czym będzie mu pomagać - wszystko na to wskazuje - Hanka Wěrikec, jego dawna uczennica, edukująca przez lata nieobecności Bosćija wiejskie dzieci.

W planie tematycznym przeplatają się trzy wielkie sfery problemowe: historia (p. obejmuje lata 1755-1763), kwestia serbołużycka, nauczycielstwo - przy tym każdy z tomów ma inną poddominantę. Pierwszy tom to najbardziej „serbołużycka” część trylogii, wielki fresk życia zamieszkujących podbudziszyńskie wsie katolickich Górnołużyczan (aczkolwiek w powieści ważną funkcję pełnią także ewangelicy). Istotną zmianą względem struktury prozy głuż., od zawsze „ruralnej”, stało się otwarcie na miasto [Budziszyn], w czasie akcji jeszcze w części słowiańskie; wprowadzenie przestrzeni miasta pozwoliło na ukazanie cechów podmiejskich jako inkubatora serbołużyckości. Druga część to tom najbardziej fabularny, o wartkiej akcji; silniej niż w pierwszym tomie zarysowany został aspekt klasowy. Na plan pierwszy rzutują dwa problemy: czy Bosćij wytrwa w swym postanowieniu i gotów będzie poświęcić miłość do kobiety dla dydaktyki; drugi to zmiana światopoglądowa: początkowo skromnie pojmowany przez Bosćija plan podstawowej edukacji dzieci urasta do posłannictwa socjalno-narodowego. Trzeci tom prezentuje się jako najbardziej „historyczny”. Odpowiada temu ustanowienie podwójnego bohatera; obok Bosćija jest nim wojna siedmioletnia, mająca wielkie znaczenie dla historii Łużyc Górnych i ich słowiańskich mieszkańców. W realizacji KUBAŠEC historie wojenne to nie historia wielkich dowódców i talentów, lecz dzieje zwykłych żołnierzy i mieszkańców terenów, przez które przetacza się wojna. Poszerzeniu planu hist. w trzeciej części cyklu towarzyszy zawężenie planu fabularnego: Bosćij obronić musi swe ideały w konfrontacji z brutalnością wojny i demoralizującym wpływem służby wojskowej. 
P. hist. zawsze funkcjonuje w podwójnym planie semantycznym: jako utwór literacki i źródło historyczne. Trylogia odznacza się starannie zaprezentowanym, acz nie bez pomyłek, podłożem faktograficznym; koncentracja uwagi na planie hist. położyła się cieniem na wartości artystycznej, autorce nie udało się zachować właściwych proporcji między planem historycznym a fikcyjnym (fabularnym). Tym, co przesądza o nikłej w dniu dzisiejszym wartości utworu, jest nierealnie oddana sfera nauczycielstwa. Pełna patosu i nieprawdopodobnych postaw nauczycieli nie przekonuje współczesnego czytelnika.

P. przedstawia się wybitnie pod względem wyzyskanych przez autorkę środków formalnych. W trylogii, także w późniejszej dylogii $\rightarrow$ Lěto wulkich wohenjow / $\rightarrow$ Nalětnje wětry, odnajdujemy szereg różnorodnych i niespotykanych zabiegów kompozycyjnych, językowych, stylistycznych. Wielką rolę odgrywa w trylogii hypodiegeza (opowiadanie postaci) przyjmująca niekiedy postać rozbudowanych, nabierających cech samodzielności fabuł, oraz gatunki wtrącone (literackie i nieliterackie). Z uwagi na determinanty p. hist. przewagę nad przestrzenią uzyskuje czas, aczkolwiek wyprawę Bosćija do Pragi uznać należy za jeden z niewielu przypadków, gdy bohater p. głuż. opuszcza teren rodzinnych Łużyc Górnych. Dla p. właściwa jest rozbudowana siatka postaci; Bosćij Serbin to postać fikcyjna, w utworze pojawiają się również postaci „rzeczywiste”; kreacja męskiej postaci głównej jest nieprzekonująca. Narrację pisarka prowadzi w „epickim praeteritum”; często występują chwilowe modyfikacje temporalne (czas unaoczniający); auktorialność narratora podkreślana w kilku miejscach przy pomocy strategii quasi-niewiarygodności; duży udział w narracji mają zdania pytajne; partie deskryptywne należą do najlepszych w obrębie prozy głuż.; nieprzekonujące, ze względu na patos i sentymentalizm, są natomiast partie dialogowe. Płaszczyzna formalna trylogii pozwala uznać M. KUBAŠEC za jednego z najwybitniejszych prozaików głuż.

Trylogia wpisuje się w nurt głuż. p. nonkonformistycznej, lokując się w bezpośredniej opozycji względem Brězanowskiej $\rightarrow$ trylogii o Feliksie Hanušu. Sięgnięcie po model cz. p. hist. (upatrywano się wpływu pentalogii F.L. Věk [1888-1906] A. JIRÁSKA, którego dwa tomy KUBAŠEC przełożyła; z powodów ideologicznych książkowo ukazał się tylko tom pierwszy [1957]) przeciwstawia się wyzyskaniu i inkorporacji do lit. głuż. kojarzonego z tradycją lit. niem. modelu p. rozwojowej (Entwicklungsroman). Trylogia obok mikropowieści J. WJELI $\rightarrow$ Pětr z Přišec funkcjonuje jako zasobnik i katalizator świadomości niezafałszowanej pamięci narodu, będącej w kulturze/lit. głuż. po 1945 r. obiektem zajadłej modyfikacji, czego przykładem były opowiadania hist. B. BUDARA; trylogia przesycona jest duchem „wzajemności słowiańskiej”, prócz wykorzystania wzorca cz. p. hist., służy temu przede wszystkim ustalenie miejscem katharsis protagonisty Pragi, wyobrażanej w konformistycznej p. głuż. tego okresu, np. w p. $\rightarrow$ Hrěšna wjes J. WINARA, negatywnie. W dwu esejach, Jich běda - naše žiwjenje (1970) oraz Historija a historiski roman (1972) KUBAŠEC broniła swej decyzji o podjęciu w dobie trwania p. socrealistycznej i socjalistycznej tematyki hist. przed zarzutami formułowanymi przez rodzimą, marksistowską krytykę literacką.

Lit. C. Piniekowa, Wobraz čłowjeka w literarnych twórbach Marje Kubašec [...], Univ. Diss. Leipzig 1983; T. Derlatka, Powieść z Górnych Łużyc: historia, poetyka, ideologia, Praha 2015. 


\section{Lěto wulkich wohenjow (Budyšin: LND 1970)}

Wraz z późniejszą p. $\rightarrow$ Nalětnje wětry, z którą stoi w bezpośredniej relacji fabularnej, składa się na dylogię z życia i działalności demokratycznie zorientowanych głuż. nauczycieli w XIX w.; ze względu na jedność formalno-tematyczną, układa się w makroskali wraz z trylogią o $\rightarrow$ Bosćiju Serbinie w cykl powieściowy.

Geneza dylogii wypływa z sukcesu, jaki osiągnęła trylogia $\rightarrow$ Bosćij Serbin. Zachęcona powodzeniem, KUBAŠEC przystąiła do pracy nad utworem o losach głuż. nauczycieli w XIX w.; pierwotnej skali projektu: jeden utwór, dylogia? - nie sposób określić. W 1966 praca nad p. była już zaawansowana;; po ukazaniu się wyimków p. w j. niem. (1970) opublikowano fragm. promujący w czasopiśmie „Rozhlad” (1970).

P. przedstawia losy grupy uzdolnionych nauczycieli głuż.: Pětra Domša, Hicki, Kocora, Rostoka, Wjeli. Spotykamy się z nimi jako żakami budziszyńskich szkół w 1842 r., w trakcie wycieczki na górę Mnišonc (Mönchswalder Berg). Młodzieńcy rozmawiają o swych przyszłych losach, symultanicznie o tym samym debatują dyrektorzy szkół. Sytuacja nie jest zachęcająca, dla większości z prymusów nie starczy miejsca w szkołach miejskich, wskutek czego zadowolić się będą musieli nisko płatną pracą w szkołach wiejskich, borykających się ponadto z niewystarczającą liczbą uczniów. Miejscem nauczania bohatera dylogii, Pětra Domša będzie mała wieś Něćin (Nethen). Po krótkim czasie Pětr zadomawia się we wsi i organizuje nauczanie w szkole. Od początku przyjdzie mu się jednak mierzyć z przeciwnościami losu; w owym roku panuje na Łużycach susza, dzieci obarczone są obowiązkiem zdobywania pożywienia, izba szkolna coraz częściej świeci pustkami; próba szkolnego festynu kończy się pożarem, który jedynie wielkim wysiłkiem udaje się opanować. W międzyczasie Pětr uczestniczy w licznych spotkaniach i debatach na temat nowych metod nauczania, które budzą w nim pragnienie reformy szkolnictwa, zwłaszcza szkół wiejskich. Sprawy dydaktyki schodzą na dalszy plan, kiedy pożary zaczynają pustoszyć najbliższą okolicę; wielki pożar Kamjenca (Kamenz), w którego gaszeniu uczestniczą dawni koledzy szkolni, daje okazję do spotkania. Pětr staje przed wyzwaniem złożenia kolejnego egzaminu; spełnia się również jego marzenie, gdy spotyka się z Handrijem ZEJLEREM (1804-1872), czołowym przedstawicielem głuż. odrodzenia narodowego. Po lecie wielkich upałów przychodzi ostra zima; do szkoły nie uczęszcza niemal nikt. Na Wielkanoc 1843 r. pojawia się przed Pětrem możliwość studiów w Lipsku, ku czemu nakłania go rodzina; propozycję nauczania w Budziszynie złożył mu również dyrektor jednej ze szkół. Pětr decyduje jednak, iż zostanie w małej wiejskiej szkole w Něćinie. Tląca się w nim, długo skrywana miłość do Herty wybucha wielkim płomieniem.

Lit. C. Piniekowa, Wobraz čłowjeka w literarnych twórbach Marje Kubašec [...], Univ. Diss. Leipzig 1983; T. Derlatka, Powieść z Górnych Łużyc: historia, poetyka, ideologia, Praha 2015.

\section{Nalětnje wětry (Budyšin: LND 1978)}

P. stoi w ścisłym, tematyczno-formalnym stosunku do wcześniejszej p. $\rightarrow$ Lěto wulkich wohenjow, tworząc wraz z nią dylogię. 
Powieść wydana pośmiertnie (autorka zmarła w 1976 r.); manuskrypt przekazała na początku 1976 r., ostatnie korekty przeprowadzała w szpitalu; wyraźne ingerencje redaktorów w tekst, ujawniające się m.in. w rozbiciu spójnego systemu graficznego oznaczania tekstu wprowadzanego, odmiennym sposobie narracji (więcej alokucji, formy pluralne w miejsce singularnych); wersja książkowa znacząco skrócona względem rękopisu. Fragm. przedpremierowy w „Rozhladzie” (1975); drugi, w dzienniku „Nowa doba” (1978), ukazał się już po premierze.

Akcja nawiązuje bezpośrednio do fabuły p. $\rightarrow$ Lěto wulkich wohenjow i przedstawia dalsze losy głuż. nauczycieli w latach 1845-1848, zatem krótko przed fermentem społeczno-polit. roku 1849. W initium dowiadujemy się o dalszych losach znanych nam nauczycieli; wiedzie im się rozmaicie, jednym lepiej, innym gorzej. Jest rok 1845, Pětr zmuszony zostaje w swej działalności dydaktycznej do rozwiązania problemu Gusty Wornača, sieroty, mieszkającego u dziadków, którzy nie dają sobie z nim rady; Pětr stara się mu ze wszystkich sił pomóc, jednak jego starania nie przynoszą efektów. Broni również dzieci przed niesłusznymi zarzutami ze strony pańskiego inspektora, oskarżającego je o kradzież ziemniaków z folwarcznego pola. Organizuje wreszcie szkolny „swjedźeń” (,festyn”), zakończoną pełnym sukcesem pierwszą tego typu w małym Něćinie (Nethen) uroczystość, która staje się przyczynkiem do integracji mieszkańców wsi i pobudzenia ich aktywności na polu działań pronarodowych. Wuj Handrij podejmuje ostatnią próbę przekonania Pětra do rozpoczęcia studiów w Lipsku, nadaremnie. Jako tło dla wydarzeń fabularnych związanych z nauczaniem i życiem wsi służą fakty koncentrujące się wokół dydaktyki i ruchu odrodzeniowego. Pionierskie, innowacyjne, a zwłaszcza prodemokratyczne techniki nauczania proponowane przez znajomego Pětra - Meldę (Jan Jurij MELDA, 1814-1894) znajdują uznanie, Pětr uważa się za przedstawiciela szkoły Meldy. Utylitarny charakter koncepcji oświaty światłego pedagoga prowadzi u Pětra do wewn. konfliktu, ponieważ z drugiej strony czuje się silnie związany z konserwatywnym, zatem antydemokratycznym skrzydłem narodowego odrodzenia Górnołużyczan. W warunkach nasilających się prodemokratycznych ruchów narodowych w Europie, zmieniających się, głównie przez rozwój kolei żelaznej, stosunków społecznych i ekonomicznych, bohater zmuszony będzie do zajęcia konkretnego stanowiska. Jednoznacznego wyboru unika, dochodząc do przekonania, iż nic nieznaczący nauczyciel w małej mieścinie nie ma wpływu na losy świata. Jedyny, jaki ma, to oddziaływanie na uczniów, którym chce pomóc na drodze do lepszego życia. Na końcu oczekuje go szczęście osobiste; Herta, podobnie jak jej rodzice, nie ma nic przeciwko temu, by zostać żoną nauczyciela. Wycieczka na Mnišonc (Mönchswalder Berg), ślub, po którym w budziszyńskiej karczmie ojca Pětra zbiera się śmietanka górnołużyckich pedagogów, kończą drugą część dylogii i zarazem cały cyk1.

Płaszczyzna tematyczna dylogii, w szczególności jej główne wątki - przy nieuniknionych, z uwagi na zmieniony czas zdarzeń, tło historyczne, socjalne, ekonomiczne, dyferencjach pojedynczych motywów - kontaminują z planem tematycznym trylogii $\rightarrow$ Bosćij Serbin. Różnica najwyższego rzędu pomiędzy obydwoma cyklami zawiera się w ustanowieniu protagonistą utworu odmiennego typu bohatera, osadzeniu go w zmienionych warunkach, oraz w znaczeniu jego działalności dla (przyszłej) historii Górnołużyczan. Dylogia ukazuje to, co na bazie działalności jednostek takich jak ubogi szewc-nauczyciel Bosćij Serbin, udało się o kilka dekad później osiągnąć kolektywowi - aktywistom odrodzenia narodowego. Zarówno ,wielkie ognie” (,wulke wohenje”), jak i „,wiosenne wiatry/wichry” 
(„nalětnje wětry”) to metafory zmagań Domša, problemów młodych nauczycieli na polu upowszechniania oświaty wśród wszystkich warstw społecznych, również na wsi, jak i kłopotów działaczy odrodzeniowych na polu pobudzania świadomości narodowej wśród Górnołużyczan. W sferze pedagogium rozróżnić należy dwie płaszczyzny. Pierwsza z nich odzwierciedla ogólne problemy związane $z$ nauczaniem, jego organizacją i funkcjonowaniem, zarówno na Łużycach, jak i w Niemczech; to zatem kwestia bardziej uniwersalna, a w szczególności niezależna od jednostki (bohatera), jej wyborów i postępowania. Drugą płaszczyznę determinują wybory protagonisty - nauczyciela, bezpośrednio związane z nauczaniem, i ich konsekwencje; sfera ta powiązana jest zarazem z jego przestrzenią osobistą. Podobnie jak w trylogii, także w dylogii KUBAŠEC idealizuje osobę i zawód nauczyciela. Wspólny jest również motyw próby; tak jak Bościj Serbin, także Pětr Domš poddany zostaje egzaminowi: swój ideał (nauczanie w wiejskiej szkole) obronić musi w konfrontacji nie tyle ze zjawiskami klimatycznymi, co z wiejskim milieu, jego podejściem do kwestii szkolnictwa, do znaczenia edukacji dla dzieci, patriarchalnym systemem społecznym, rzutującym na system przekonań wsi. Historia powszechna, stanowiąca dominantę trzeciego tomu trylogii $\rightarrow$ Bosćij Serbin, ustępuje w cyklu dwuczęściowym miejsca dziejom narodowym. Zakończenie akcji dylogii przed rokiem 1849 wynikało z waloryzacji nie tylko w planie „historycznym”, bo również w ogólnej wymowie, głuż. ruchu odrodzeniowego. Zachowawcze stanowisko najważniejszych, obecnych w dylogii „fizycznie” postaci ruchu narodowego, opowiadających się za zachowaniem dotychczasowego status quo, względem procesów demokratycznych nie zostało przez KUBAŠEC przedstawione expressis verbis. Semiosferę historii narodowej wypełnia w obu częściach cyklu mnóstwo konkretnych, hist. poświadczonych detali.

Dla dylogii znamienne są te same niedostatki, co dla trylogii $\rightarrow$ Bosćij Serbin, tyle że występują one w obu tomach w spotęgowanej formie. W dylogii sroży się, zniechęcający do dalszej lektury wszechobecny patos; nie przekonuje finalny chwyt klamrujący. Identyczne dla obu cykli są typy bohatera, schemat fabularny (decyzja protagonisty, zagrożenie miłości) oraz przesłanie, przez co dylogia o nauczycielach może funkcjonować jako sequel $\rightarrow$ Bosćija Serbina. Autorka pozostała wierna sprawdzonym we wcześniejszej trylogii rozwiązaniom w planie formalnym; epicka różnorodność dylogii, niespotykana na taką skalę u innych powieściopisarzy głuż., dorównuje poziomem cyklowi o Bosćiju Serbinie. Dylogia posiada kompozycję quasi-ramową, wygenerowaną przez powtórzenie motywu wycieczki na Mnišonc. Na podobieństwo wyprawy Bosćija Serbina do Pragi, obie części dylogii posiadają jednostkowe fabularne punkty kulminacyjne; w $\rightarrow$ Lèto wulkich wohenjow jest to spotkanie u H. ZEJLERA (znaczenie tej sceny potwierdzone zostało wybraniem jej jako zwiastuna opublikowanego przed wydaniem książkowym), natomiast w Nalětnich wětrach - szkolne święto w Něćinie. Obie części dylogii określić należy jako wyjątkowo statyczne fabularnie, co stanowi dla czytelnika, zwłaszcza współczesnego, poważne wyzwanie. W obszarze dylogii przejawia się również zbyt silna predylekcja autorki dla detalu, co zaburza stosunek pomiędzy szczegółowością a uogólnieniem - praktycznie nie występuje strefa pośrednia. W dylogii silniej niż w trylogii dochodzi do głosu tendencja do ustanowienia bohatera równorzędnego względem Domša - to kolektyw działaczy odrodzeniowych; szczególnie ważki staje się dialog, poprzez który, zwłaszcza w Nalětnich wětrach, przekazywany jest cały konflikt. 
Lit. C. Piniekowa, Wobraz čłowjeka w literarnych twórbach Marje Kubašec [...], Univ. Diss. Leipzig 1983; T. Derlatka, Powieść z Górnych Łużyc: historia, poetyka, ideologia, Praha 2015.

\section{MEYNKOWA, Marja [1934-1971]}

\section{Dny $w$ dalinje (Budyšin: LND 1968)}

Jedyna w dorobku głuż. pisarki, literaturoznawczyni, krytyczki, tłumaczki i redaktorki (,Serbska šula”) dłuższa proza dla czytelnika dorosłego. Koncypowana jako opowiadanie; prymarna tytulatura Nan (Ojciec), poświadczona także forma $W$ dalinje ( $W$ oddali); fragm. w 1965, 1967 i 1968 r. w periodykach głuż.; wyd. drugie jako drugi tom Zhromadźenych spisow (1994). P. uhonorowana nagrodą literacką organizacji Domowina drugiej klasy w roku wydania; szeroki odgłos za granicą: fragm. w wielu j., m.in. słow. (1968), pol. (1969, 1971, 1991); pełny przekład na j. cz. jako Dny v dálce (tł. J. VLÁŠEK, 1973; planowana była również ekranizacja filmowa), słow. jako Dni v dial’ke (tł. V. GAŠPARÍKOVÁ, 1984); prawdopodobny przekład na język polski autorstwa slawisty, F. BIZONIA, fragm. zachowane w Serbołużyckim Archiwum Kulturalnym (Serbski kulturny archiw) w Budziszynie.

Składające się na przebieg fabularny wydarzenia ukazywane są przez narratora pierwszoosobowego w technice retrospektywnej. Akcja toczy się w latach 1932-1942 i przedstawia losy nauczyciela głuż. w czasach rodzącego się faszyzmu oraz wojny. Bohater to Górnołużyczanin [w rzeczywistości ojciec autorki: Mikławš BRĚZAN; 1900-1972], z wykształcenia nauczyciel, który po zakazie wykonywania zawodu na Łużycach Górnych nauczać musi w dolnośląskiej (Friedersdorf, dziś Ługi koło Zielonej Góry) szkole śpiewu i muzyki. Zadłużony przez lekkomyślne wydatki u miejscowego inspektora, zmuszony zostaje przezeń do poślubienia jednej z jego trzech chrześnic, córek bogatego junkra. W niekonwencjonalny sposób, na podstawie zdjęć, nauczyciel dokonuje wyboru jednej z sióstr, Lejny. W rzeczywistości nieurodziwa Lejna nie przypada mu do gustu, rozczarowany inspektor grozi bohaterowi wyciągnięciem konsekwencji; bohater tłumaczy się jednak, jakoby wskazał na inną siostrę, wykształconą we Wrocławiu u urszulanek Hildę (Hildegard Magdalene z domu Klapper; 1909-1940), oczko w głowie matki. Pomimo sprzeciwu junkierki, inspektorowi udaje się zaaranżować spotkanie młodych podczas wycieczki na Górne Łużyce, na którą zaprosił Hildę. Ta nie jest zachwycona, nie tyle samym nauczycielem, co jego rodzimym środowiskiem; w jej przekonaniu matka nie zezwoli na ślub, sama też czuje się w tej okolicy obco. Obiekcje Hildy rozwiewa inspektor wskazując, że dla niemieckiej rasy nastaje właśnie dobry czas, natomiast kwestia Serbołużyczan rozwiąże się sama. Po wielokrotnych ponagleniach swata-inspektora nauczyciel oświadcza się Hildzie następnego dnia na zaniedbanym dworcu kolejowym [sic!]. Czas upływa; młodzi korespondują ze sobą; nauczyciela odwiedza jego brat bliźniak, Jurij [Jurij BRĚZAN; 19001948], student teologii w Pradze. Jurij sprzeciwia się małżeństwu brata z Hildą ze względu na nieskrywane prohitlerowskie sympatie deklarowane przez jej rodzinę. Rozmowa z bratem otwiera bohaterowi oczy; dostrzega problem stosunku narodowych socjalistów do Serbołużyczan; na tle akceptacji/braku akceptacji założeń faszyzmu dochodzi do jawnego 
konfliktu nauczyciela z inspektorem; sytuację łagodzi zbliżający się ślub i wystawne, trzydniowe wesele. Między Mikławšem a Jurijem dochodzi do otwartej waśni na tle pochodzenia i polit. orientacji rodziny Hildy, kłótnia kończy się deklarowanym zerwaniem wszelkich stosunków; napięte stosunku panują również między nauczycielem a Hildą. Nowożeńcy przenoszą się na Łużyce, jednak tylko po to, by zaraz przeprowadzić się do odległej dolnośląskiej wsi, przy granicy z Polską. Przyjdzie i Mikławšowi, i jego rodzinie, wegetować w niesprzyjających warunkach; jako nauczyciel może liczyć jedynie na niską płacę. W kolejnych latach $\mathrm{w}$ relacjach między małżonkami przeplatają się okresy lepsze i gorsze; bohater odkrywa bliskość losów Polaków i Serbołużyczan; postanawia budzić w miejscowych dzieciach świadomość polską. Hilda rodzi pierwsze dziecko, na chrzcinach ponownie spotykają się obie rodziny, przybywa również Jurij. Wieś się przemienia, wzrastają nastroje prohitlerowskie; Mikławšowi składa wizytę poszukująca Jurija policja; proponują mu również do przystąpienie do SA (odmawia); wójt omyłkowo zapisuje, iż nauczyciel włada językiem serbskim; w trosce o zabezpieczenie egzystencji swej rodzinie bohater wstępuje do Grenzschutzu; nauczycielowi i Hildzie rodzi się drugie dziecko. Wybucha wojna; nauczyciel powołany zostaje do Wehrmachtu; przerzucony na teren Polski nawiązuje kontakty z ruchem oporu; poznaje uświadomioną narodowo polską nauczycielkę, Łuc[j]ę Kaczmarek, w której, jak można się domyślać, zakochuje się z wzajemnością. Dobrą wiadomość o tym, że po raz trzeci zostanie ojcem, przesłania wkrótce tragiczna: przy poronieniu zmarło zarówno dziecko, jak i Hilda. W opuszczonej dolnośląskiej wsi ponownie spotykają się obie rodziny; bohater odwozi dzieci na Łużyce, gdzie od tej pory będzie się o nie troszczyć jego rodzina. Bohater - awansowany w międzyczasie do rangi oficera, zostaje skierowany do Serbii, na podstawie posiadanych przez armię informacji, jakoby mówił po serbsku. Daleko od rodzinnych stron dokonuje się w bohaterze przełamanie; pewnej nocy dokonuje aktu sabotażu, wypuszczając na wolność zatrzymanych jugosłowiańskich jeńców, za co, jak dowiadujemy się z lakonicznej narracyjnej prolepsy, postawiony zostanie w przyszłości przed sądem wojennym pod zarzutem zdrady.

Brak wariantu niem. spowodował, iż p. omawiana była głównie w kręgu słow.; rodzime literaturoznawstwo z uwagi na jej odmienność od obowiązującego wówczas modelu socrealistycznego zajmowało się nią niechętnie i powierzchownie. Stąd też wymiar, znaczenie oraz wartość Dni w oddali dla hist. prozy (lit.) głuż. odkryto z opóźnieniem, za zasługą sorabistyki zagranicznej.

Plan tematyczny p. jest niezwykle bogaty i zróżnicowany. Utwór funkcjonuje jako rodzaj kroniki rodzinnej, narodowej, także jako hist.-kulturowy zapis ówczesnej doby; łączy wiele motywów znanych z p. innych autorów głuż. (wojna, rodzenie się faszyzmu, emigracja, wewnętrzna emigracja, nauczycielstwo, kontakty z partyzantami, obrachunek generacyjny). Przy rozbiorze planu tematycznego kluczową funkcję pełni tytuł; funkcjonuje on jako pryzmat, przez który oświetlać i przy pomocy którego objaśniać się dają kolejne jej wątki; motywem oddali, geograficznej i uczuciowej, jako determinanty losu ludzkiego koresponduje z najwybitniejszą p. wojwodińskich Słowaków, z utworem $\rightarrow$ Dial'ky J. LABÁTHA.

Cechę znamienną p. stanowi autentyzm, jakkolwiek z uwagi na liczne tematyczne pierwiastki, których zidentyfikować niepodobna, fabułę uważać należy za fikcję; w ocenie współczesnych, wszystkie postaci ze strony głuż. były postaciami autentycznymi. Niespotykane jest skonfigurowanie (meta-)relacji zachodzącej między realnym autorem 
(M. MŁYNKOWĄ) a protagonistą: bohater to w rzeczywistości ojciec autorki; sama M. MŁYNKOWA funkcjonuje w przestrzeni związanej $\mathrm{z}$ tekstem $\mathrm{w}$ trzech wymiarach: w pozatekstualnym jako realna autorka oraz podwójnie w sferze wewnątrztekstowej: jako instancja zbliżona do narratorki i zarazem jako jedna z postaci (,urodzi się" w drugim roku fabularnym p., natomiast w chwili, kiedy jej ojciec zadecyduje o uwolnieniu jugosłowiańskich partyzantów, liczy około ośmiu lat). Umieszczenie zdarzeń poza terenem Łużyc, „w oddali”, w sposób naturalny ewokuje odmienny od zasadniczego dla p. głuż., bo ekstraspektywny, ogląd sytuacji Serbołużyczan z Łużyc Górnych. Dny w dalinje tworzą rysę na nieskazitelnym wizerunku nauczyciela, propagowanym dotąd w prozie głuż. (M. KUBAŠEC, J. WJELA). Dotychczasowi literaccy Górnołużyczanie-nauczyciele nie tylko w szkole, lecz również w życiu osobistym kierowali się ideałami przyświecającymi im w pracy, natomiast ocena sfery prywatnej Mikławša jest co najmniej ambiwalentna.

Nowością wnoszoną przez p. MŁYNKOWEJ do prozy głuż. był pogłębiony rys psychologiczny postaci. Niekorzystne położenie protagonisty, Górnołużyczanina w dolnośląskiej, konsekwentnie faszyzującej się wsi, niezrozumienie z najbliższymi osobami: z Hildą, ale także z bratem Jurijem, w sposób naturalny otwiera przestrzeń dla silniejszego niż miało to miejsce w dotychczasowej, przede wszystkim deskryptywnej prozie głuż., zaakcentowania stanów emocjonalnych bohatera. MŁYNKOWA umiejętnie przedstawia, w stałym balansie z czynami pozytywnymi, repertuar negatywnych działań i przymiotów bohatera: kunktatorstwo, bierność, niekiedy konformizm (sposób rozwiązania problemu długu, małżeństwo z niekochaną kobietą, wstąpienie do niemieckiej armii, udział w wyprawie do Polski i Jugosławii). MŁYNKOWA to także pierwszy głuż. powieściopisarz, który przedstawił konflikt mieszanego głuż.-niem. małżeństwa (pojawiający się częściej w dalszych dekadach rozwoju prozy głuż.), w szczególności w wymiarze psychologicznym. Poprzez zaznaczenie sytuacji niezrozumienia między małżonkami w sposób zakładany bądź nie zarysowała się także konfrontacja obu narodów, głuż. i niem. To zaś uwidacznia się przede wszystkim w kontrastywnym ukazaniu przez autorkę obu semiosfer: nauczyciela, jego rodziny i narodu, oraz Hildy, jej rodziny i jej narodu.

Bohater, Mikławš, to człowiek moralnie i psychicznie słabszy, acz nie słaby: przeciętny, targany ogólnoludzkimi problemami i strachem. Omawiana p. to subtelne studium degradacji psychiki, zachowań, godności ludzkiej, skażenia obyczajów i relacji - nawet między małżonkami, pod nieustannym i wszechobecnym wpływem ideologii faszystowskiej, strachu, konformizmu. Niezależnie od oceny jego postępowania, bohater to kreacja dla prozy głuż. całkiem nowa, niezwyczajna i niezaakceptowana przez rodzimych czytelników. Całkowita zależność losu bohatera od czynników zewnętrznych, deziluzja i indyferencja to wyznaczniki i realizacja kafkowskiego typu bohatera. Na tle innych bohaterów p. i prozy głuż. wyróżnia go brak jednoznacznego zadeklarowania przez autorkę - i przez siebie samego - jako Górnołużyczanina.

Nie tylko w kwestiach tematycznych, lecz i w planie formalnym Dny $w$ dalinje wybijają się ponad dotychczasowe i wielką część kolejnych osiągnięć powieściopisarstwa Górnołużyczan. Za zjawisko wyjątkowe uznać należy obejmującą trzydzieści jeden zdań ekspozycję, niepowtarzającą się w takiej lub podobnej postaci w żadnej innej p. głuż. Pełni ona funkcję inicjalnego metakomponemu, od komponemu właściwego odróżniając się przede wszystkim odmienną, pierwszoosobową formą narracji (następnie narracja przechodzi do formy 3 os. sg., przeplatanej krótkimi wtrętami w ,ja"-formie) oraz odniesieniami 
do rzeczywistości pozatekstowej. W obrębie krótkiego fragmentu zbudowana zostaje sfera przesyconych emocjami napięć wewnątrzrodzinnych (rodzina niem., rodzina głuż.), w których odnajdujemy odbicie rzeczywistej, niebanalnej sytuacji zarówno bohatera powieści, ojca autorki, jak i niej samej. Opowiadacz nie prezentuje się jako instancja spolegliwa; $\mathrm{z}$ jednej strony odnajdziemy w tekście dowody bezpośrednio wskazujące na jego omnipotencję, z drugiej - partie świadczące o tym, iż to jednak instancja niewiarygodna. Językowe i fabularne realizacje konstrukcji narratora „nieautorytatywnego" w Dniach w oddali należą do najlepszych i najciekawszych w obrębie p. i prozy głuż.

Skarb powieści stanowi forma narracji. Dny $w$ dalinje to najlepszy przykład konwencji skazu w prozie głuż., konwencji realizowanej przez m.in. wielką ilość zwrotów nieliterackich, typowych dla mowy potocznej; pomijanie niektórych faktów, z punktu widzenia narratora i odbiorcy komunikatu zbędnych; wtrącanie innych, nie związanych z prezentowanymi zdarzeniami; repetycja słów i zwrotów; ekspresja wypowiedzi; wulgaryzmy; zmienność rytmu opowiadania. Rozwiązania formalne oraz stopień nasycenia narracji elementami skazu lokują MŁYNKOWĄ wśród najlepszych słow. reprezentantów tej konwencji (por. także $\rightarrow$ Twarz Smętka J. DRZEŻDŻONA).

Dny $w$ dalinje to jedna z najwybitniejszych p. głuż. Żaden z powieściopisarzy głuż. do dnia dzisiejszego nie powtórzył kompleksowości rozwiązań formalno-tematycznych wprowadzonych przez autorkę do gatunku. Niekonwencjonalny, stojący w oczywistej opozycji względem modusu opowiadania w dominujących w tym czasie p. socrealistycznych i socjalistycznych sposób narracji stanowił dla autorki (w działalności krytyczno-literackiej wychodziła z marksizmu) podstawowy, zarazem odmienny od koncepcji autorów starszej generacji sposób odideologizowania powieści głuż.

Lit. F. Šěn, Dosłowo, [w:] M. Młynkowa: Zhromadźene spisy, 2. zwjazk, Budyšin 1994; C. Prunitsch, Nachwort, in: M. Młynkowa, Tage in der Ferne, Bautzen 2003; T. Derlatka, Powieść z Górnych Łużyc: historia, poetyka, ideologia, Praha 2015.

\section{VÁŠOVÁ, Alta [*1939]}

Po (Bratislava: Slovenský spisovatel' 1979)

Pierwszy z projektów SF słow. autorki, po którym ukażą się jeszcze $\rightarrow V$ Záhradách, Blíženci z Gemini (1981), 7,5 stupňa Celzia (1984); pierwsza „kobieca” p. SF oraz pierwsza próba antyutopii w lit. słow.

P. ukończona już w 1974; negatywne, zarzucające autorce wzorce lit. zachodniej recenzje wydawnicze spowodowały, iż wydawnictwo „Tatran” utwór odrzuciło; pierwsze wydanie w oficynie „Slovenský spisovatel” ocenzurowane; pierwotny, podkreślający antyreżimową wymowę utworu, wariant p. oddaje dopiero wyd. drugie (1993); prymarna forma tytułu Herci; tekst właściwy poprzedzony fragm. wiersza (At’ se stalo) cz. pisarza, F. HALASA, zamykającego tom poetycki Naše paní Božena Němcová (1940; „At’ se stalo jak se stalo / dosti zlé je že se stalo / jeden zajde druhý přijde / slunce zašlo slunce vyjde"), mający wielkie znaczenie dla interpretacji poszczególnych kręgów tematycznych oraz całego utworu. 
Wybudzony (w nieznany sposób) z hibernacji bohater-robot (imię lub oznaczenie nieznane) w poszukiwaniu wyczerpujących się zapasów energii porusza się ostrożnie po najbliższej okolicy, odnajdując jedynie ruiny i ciała innych robotów („,celá planéta bola vtedy obrovským cintorínom"). Budzi się w nim myśl o ożywieniu tego cmentarzyska; wśród ruin odnajduje innego, podobnego do siebie robota, którego udaje mu się częściowo ożywić; zdaje sobie sprawę, że staje się tym samym panom nad smrtou i określa siebie mianem konstruktora („konštruktér”). Gromadzi zasoby energii, zabezpieczając w ten sposób swoją egzystencję oraz pozycję w przyszłym społ. ożywionych robotów. Ostatecznie wybudza znalezionego wcześniej robota, nazywając go bratem; jednocześnie konstruktora nachodzi refleksja, że i on sam został przez kogoś stworzony. Przywracanie do funkcjonalności kolejnych robotów idzie gładko, jednakowoż te, wśród nich i brat, instynktownie dążąc do pozyskania niezbędnego zasobu energii, atakują konstruktora; ten wycofuje się do kryjówki, w której odtąd spędza większość czasu. Ćwiczy pamięć przestrzenną; przenosi do kryjówki i ukrywa brata; odnajduje również swój słaby punkt - wyłączniki, które maskuje barwnymi przykrywkami. Robotom-obywatelom przydziela kolejne zadania do wykonania oraz teren, na którym będą przebywać; konstruktor dowiaduje się, że poprzednim operatorem-konstruktorem robotów, w tym i jego samego, była instancja zwana człowiekiem. Stworzone przez konstruktora społ. robotów funkcjonuje bezproblemowo; konstruktor włada suwerennie; rozwija się nauka, roboty uczą się i dochodzą do kolejnych odkryć (moda, ogień, klonowanie); roboty-naukowcy, prócz pracy, zaczynają się interesować przeszłością, prowadzą badania. Konstruktor nadaje bratu pełną funkcjonalność, ładuje mu również kopię swojej pamięci, od tej pory brat funkcjonuje jako jego klon. W trakcie jednej z wycieczek odnajduje nieznaną, miękką istotę, która posługuje się mową (w rodzaju żeńskim); by nie stała się przedmiotem negatywnego zainteresowania, umieszcza ją w kryjówce, gdzie będzie przebywać wraz z bratem. Naukowcy uświadamiają sobie, że stworzył ich człowiek, ich przodek; zakładają muzeum, w którym eksponatami jest różnego rodzaju broń; stwarzają nazwy dla nieznanych przedmiotów. Konstruktor prowadzi rozmowy z nieznaną istotną, rozmowy są utrudnione, jako że posługuje się ona znacznie bardziej zaawansowanym słownictwem; konstruktorowi udaje się dowiedzieć, że ludzie stworzyli bombę antropologiczną („humánná bomba”), której użycie w czasie wojny zniszczyło rodzaj ludzki, pozostawiając wszystko inne, co nieożywione, nietknięte. Miękka istota, człowiek o imieniu Anna, określa się jako „chora”; jej ciało jest pełne sztucznych narządów, przy życiu utrzymuje ją skomplikowana aparatura. Roboty pilnie uczą się barw i kolorów; przełożony naukowców, 111-9-B, doprowadza do sprawności znaleziony telewizor; na filmie można obejrzeć prowadzących wojnę ludzi. Konstruktor sporządza kilka własnych kopii, które monitorują cały areał i całe społ. Roboty odkrywają podróżowanie, jej ułatwieniem jest transportacja; naukowcy przechodzą na system kartoteki: zapisują i katalogują wszystkie odkrycia; odkrywają, że najważniejszymi dla ludzi pojęciami były zawiść, seks, ból, miłość. Annie dokucza samotność, domaga się towarzystwa; aczkolwiek obywa się bez jedzenia, energię pozyskuje bowiem z baterii, żąda czegoś do jedzenia; przyrządzona wedle jej wskazówek mikstura okazuje się kwasem; Anna zarzuca naukowcom próbę otrucia, niektórzy z nich ulegają silnemu poparzeniu. Wskutek przebywania z człowiekiem zmienia się światopogląd brata: nie wyklucza w przyszłości współpracy robotów z człowiekiem. Naukowcy odkrywają sposób, w jaki reprodukowali się ludzie; chcą przy jego pomocy produkować nowe roboty; w społ. robotów narasta bunt. Konstruktor decyduje się skopiować 
człowieka, Anna jest zainteresowana. 111-9-B wraz ze współpracownikami przystępuje do zadania; wpierw konstruują mniejszy aparat podtrzymujący funkcje życiowe, Anna nie musi już korzystać w wózka; następnie kopiuje jej wyobrażenia i wiedzę, stwarzając kolejnych aktorów (hercov) rodzaju żeńskiego: Xenię, Beátę, Norę. Początkowo wszystko układa się dobrze, powoli jednak Anna zaczyna uważać aktorki za rywalki; snuje dalekosiężne plany, planuje przywrócić człowiekowi należną mu, nadrzędną pozycję; za swego sprzymierzeńca uważa 111-9-B; ten wyjawia, iż wraz z naukowcami odnalazł zahibernowanego w lodzie człowieka (mężczyznę). Anna, brat i stojedenastka organizują pucz; przy próbie fizycznej likwidacji konstruktora Anna przy pomocy kwasu unicestwia brata; aktorkom udaje się uciec. Konstruktor wraz z wiernymi mu naukowcami przechodzi do kontrataku; wybucha zaciekła walka; obie strony masowo klonują swych żołnierzy, w wyniku czego dostępne zasoby energii dramatycznie spadają. Oddziały konstruktora osiągają przewagę; akolici Anny wycofują się do muzeum; Anna ucieka; w wybuchu spowodowanym aktywizacją dawnych, przechowywanych w muzeum, bomb, ginie 111-9-B. Wybuch zniszczył wielką część świata robotów; koniec ich cywilizacji nadciąga nieubłaganie. Anna osiąga przewagę militarną; jednocześnie zaczyna zachowywać się jak królowa: buduje pałac, zakłada koronę, zbiera złoto. Aktorki pragną zobaczyć i ożywić zamarzniętego człowieka; mają nadzieję, że to mężczyzna, co umożliwi rozmnożenie rodzaju ludzkiego. Jozef staje na wysokości zadania, Xenia zachodzi w ciążę. Brak energii skłania konstruktora, naukowców i ludzi do drastycznego kroku, regulowanego umową: w celu oszczędności energii, ludzie mają zakonserwować naukowców i konstruktora, następnie przywrócić ich do życia w sprzyjających warunkach. Wszyscy stają się świadkami zagadkowej śmierci Anny w jej pałacu; Xenia rodzi córkę, naukowcy zostają zakonserwowani i wyłączeni. Ostatnie słowa robota/utworu brzmią: ,vypínam sa” („wyłączam się”).

Po, podobnie jak 7,5 stupňa Celzia, jest p. SF w konwencji postkatastroficznej, VÁŠOVÁ wykorzystała szereg wielkich tematów światowej fantastyki naukowej. Jednym z nich jest wizja końca świata ludzi, co sygnalizuje już sam tytuł: przyimek prosty „po” (tu w pozycji samodzielnej), wskazuje na zaistniałą wcześniej sytuację zakończenia określonego stanu, w tym przypadku sytuację po końcu świata. Przyczyną końca świata ludzi są oni sami, winny jest przede wszystkim rozwój cywilizacyjny i związany z nim postęp technicznych; Po wpisuje się w autodestrukcyjny nurt światowej SF, problematyzujący kwestię odpowiedzialności za rozwój techniczny.

Drugim z wielkich tematów SF jest świat po katastrofie (tu: po wojnie; w niecenzurowanej wersji przyczyną końca świata ludzi jest katastrofa ekologiczna). W realizacji VÁŠOVEJ rodzaj ludzki, z wyjątkiem dwu egzemplarzy, nie istnieje. Ze znanego nam świata pozostały jedynie artefakty nieożywione, w ten sposób „nowe” życie funkcjonować będzie w „starych” warunkach. Pisarka nie tworzy zatem całkiem nowego porządku, odtwarza, w nowych realiach i przez innych wykonawców, świat znany czytelnikowi, co jest krokiem właściwym dla zawieranego między autorem i czytelnikiem ,,paktu fantastycznonaukowego”. Odbudowa świata w Po możliwa jest jedynie poprzez dwie drogi: przez narodziny nowego życia (porządku) lub przez dyktaturę, wojnę, zniszczenie. Odbudowa, stworzenie świata na nowo lokuje $P_{o}$ w kontekście właściwego dla wszystkich kultur ludzkich mitu założycielskiego.

Kolejny wtopiony do fabuły utworu wielki temat SF stanowi sztuczna inteligencja. Wybuch bomby przeżyła część robotów, wśród nich konstruktor, aczkolwiek nieznany jest sposób lub też przyczyna jego samowzbudzenia. Sztuczna inteligencja w jego osobie przy- 
wraca życie na ziemi, stwarza nowy porządek; demiurgiem świata po katastrofie będzie zatem w wyobrażeniu autorki sztuczna inteligencja. Okaże się jednak, że społ. robotów trapić będą podobne konflikty i problemy, co wcześniej społ. ludzkie. Roboty wprawdzie się uczą, sztuczna inteligencja będzie w stanie samodzielnie zdobywać wiedzę, jednakowoż zapalnikiem konfliktu i buntu staje się dostęp do życiodajnej energii; z tego powodu wybucha główny, tragicznie kończący się konflikt robotów z robotami, a także szereg pomniejszych, przypominających ludzkie konflikty o wpływy.

Nie należy zapominać i o temacie współistnienia człowieka z maszynami, przedstawionym w Po w wielu płaszczyznach, realizacjach i perspektywach. Na plan pierwszy wysuwają się sytuacje symbiozy i konfliktu. W nowym świecie współistnienie ludzi i robotów będzie nieuniknione, wskazuje na to początkowe zachowanie Anny, zmiana światopoglądu brata, motyw aktorek - czyli pół ludzi-pół robotów, udana reprodukcja między człowiekiem a maszyną. Spoiwem między światem maszyn a światem człowiekiem są Xenia i Jozef oraz 111-9-B. Ci pierwsi to symbol odwiecznego i właściwego dla rodzaju ludzkiego (lub półludzkiego w przypadku Xenii) pragnienia miłości; również pragnienia podtrzymania ,ludzkości” w świecie bez człowieka; robot 111-9-B (liczba 111 jest znacząca; pojawia się zarówno w historii lotów kosmicznych jako numer jednej z rakiet, jak i w tablicy pierwiastków [roentgen]), klonuje człowieka, jak i sprzymierza się z Anną przeciwko innej maszynie, konstruktorowi. Sytuacja konfliktu między człowiekiem a maszyną (sztuczną cywilizacją) przebiega najogólniej pomiędzy konstruktorem a Anną, przy czym dla człowieka przeciwnikiem są wszystkie roboty, podczas kiedy dla konstruktora jedynie ona sama (zarówno aktorki, jak i Jozefa zachował przy życiu). W utworze człowiek ma wartość ambiwalentną: Anna, w czwartej dekadzie życia, to postać wybuchowa, konfliktowa, zaborcza i egoistyczna, personifikująca wszelkie negatywne cechu rodzaju ludzkiego; Jozef natomiast jest poczciwym wędkarzem, bez cech negatywnych. Sztuczna inteligencja w postaci robotów wykreowana została pozytywnie. Ich bezwzględność, konstruktor uśmierca jednego z robotów w celu pozyskania jego energii, wynika z prawa walki o przeżycie; stopniowo jednak i konstruktor, i inne roboty (brat, naukowcy), podlegają procesowi uczłowieczenia; konstruktora cechuje altruizm, zdolność do ofiary (z siebie samego), humanizm. W ten sposób VÁŠOVÁ dokonuje w Po znaczącej modulacji: cechy ludzkie przypisuje sztucznej inteligencji, wychodząc w ten sposób poza popularny schemat SF, wedle którego stanowi ona element zagrożenia.

Za oryginalny dla słow. SF uważać można charakterystyczny dla fantastyki naukowej VÁŠOVEJ motyw odnowy życia, dostrzegalny również w p. $\rightarrow$ Váhradách, przy czym w Po odbywa się to dwukrotnie: na początku odtwarzają świat roboty, następny - po wojnie robotów z człowiekiem - stworzyć muszą ludzie.

Dla Po, podobnie jak dla całej prozy VÁŠOVEJ, istotną rolę odgrywają kwestie imion, płci i tytułu. Etymologię imienia Anna oddać można jako „miłości pełna, miła, powabna”, co akurat w przypadku postaci z p. nie znajduje zastosowania, natomiast znaczenie imienia Józef, „niech przyda, pomnoży Jahwe”, oddaje jego funkcję w fabule. Dwójka ludzi, którzy przeżyli katastrofę i stworzą życie na nowo, nie zostali oznaczeni jako Adam i Ewa, pisarka uciekła tym samym od utartego schematu. Pisarka-kobieta stworzyła w Po świat zdominowany przez kobiety; roboty są z natury rzeczy bezpłciowe, kobietami, oprócz jednej z postaci głównych, Anny, są także aktorki; pierwszym dzieckiem z krzyżówki człowieka i pół-maszyny będzie córka; rola jedynego mężczyzny w utworze (w przyszłym 
świecie) ogranicza się właściwie jedynie do aktu zapłodnienia. Niepowtarzalną formę tytułu, Po, odnosić można do szeregu planów znaczeniowych utworu, z których, prócz wyjaśnionych, zwrócić należy uwagę na antyreżimowość.

Podzielony na 29, oznaczonych cyframi rzymskimi rozdziałów utwór poświadcza także interesujący plan formalny, szczególnie w aspekcie narratologii. Narracja prowadzona jest przez homodiegetycznego narratora, czyli jednocześnie protagonistę. Jest nim konstruktor, przy czym swą wypowiedź w ,ja”-formie prowadzi w dwóch płaszczyznach temporalnych. Pierwszą stanowi jego wypowiedź do siebie samego (monolog), drugą późniejsza względem monologu wypowiedź o charakterze monologicznym (tj. bez odpowiedzi ze strony adresata) w funkcji komentującej, kierowana do aktorek, w czasie na chwilę przed aktem samowyłączenia; w utworze praktycznie nie występują dialogi. Co najistotniejsze, oba plany temporalne są pasmem zdarzeń teraźniejszych, podkreślanym za pomocą gramatycznego czasu teraźniejszego; oba zróżnicowane również zostały rodzajem pisma: pierwszy, znacząco obszerniejszy, oddawany jest antykwą, drugi kursywą. Informacje istotne dla rozwoju fabuły tudzież zrozumienia utworu przekazywane są nie w jednym, lecz w obu planach. Sposób podania faktów, prezentacji zdarzeń to komunikat jałowy, konkretny, przypominający nomen omen język „maszynowy”.

W planie językowym p. spotykamy się z ciekawą tendencją, swoistą językową (pragmatyczną i symboliczną) obrazowością, jako że Anna zmuszona jest do objaśniania robotom rzeczy (np. okna, mikser), zjawisk, uczuć (miłość, seks) im nieznanych. Na paradoks w tym zakresie zwrócił uwagę D. SLOBODNIK, gdyż mający wielkie problemy z pojęciem zjawisk z obszaru ludzkiej rzeczywistości konstruktor opowiada o tychże zjawiskach aktorkom w sposób wcale profesjonalny. Właściwa dla poetyki SF futurologiczna terminologia w warstwie leksykalnej pojawia się w Po w minimalnym zakresie.

W utworze łatwo odnaleźć liczne pierwiastki intertekstualne, nawiązujące z jednej strony do światowej SF, z drugiej do zsłow. realizacji. Akt tworzenia przez konstruktora ożywionej (nawet jeśli nadal sztucznej) inteligencji, odtworzenie samego siebie w postaci brata sytuuje p. VÁŠOVEJ blisko Frankensteina (1818) M. SHELLEY, a społ. robotów, tworzenie świata na podstawie miłości - dramatu R.U.R. (1920) cz. pisarza K. ČAPKA.

Wprowadzające do Po motto z wiersza F. HALASA, będące prymarnie reakcją poety na sytuację w protektoracie, natomiast po 1945 r. wykorzystywane jako element krytyki systemu komunistycznego, w sposób oczywisty zwraca uwagę na antyreżimowy wygłos utworu, co stało się jasne również dla ówczesnych cenzorów. P. jest klarowną krytyką totalitaryzmu, poprzez motto z wiersza HALASA zrównanego z faszyzmem, który, wedle jego słów, jak każdy reżim i wszystko inne na świecie, kiedyś przeminie. W fikcyjnym społ. robotów odnajdziemy szereg cech reżimu komunistycznego: absolutną władzę, brak wolności, pseudodemokrację, totalitaryzm, manipulację. Dodatkowo, co jeszcze silniej występuje $\mathrm{w} \rightarrow V$ Záhradách, widoczna jest demaskacja utopijnych wizji szczęśliwego i beztroskiego jutra społ. socjalistycznego kolportowanych przez reżim. W tej optyce staje się jasne, że wybór konwencji SF (początkowo miała to być tematyka hist.) był dla VÁŠOVEJ także krokiem pragmatycznym, zaszufladkowana od czasu debiutów do prozy „modelowej” poszukiwała innego, alternatywnego sposobu wypowiedzenia.

Lit. D. Slobodnik, Alta Vášová: Po, „Slovenské pohl'ady” 96, 1980, nr 5; D. Hevier, Pred, „Romboid” 15, 1980, nr 11; M. Ferko, Dejiny slovenskej literárnej fantastiky, Bra- 
tislava 2007; J. Štrasser, A. Vášová, Sledoslov: rozhovory s Altou Vášovou, Bratislava 2015.

\section{Záhradách (Bratislava: Smena 1982)}

Trzeci w dorobku VÁŠOVEJ utwór w konwencji prozy SF; druga p.; polisemiczny, o charakterze kulturowego i lit. palimpsestu.

Pomimo jednoznacznego stanowiska słow. literaturoznawstwa, przynależność do gatunku p. sporna; cechy strukturalne (objętość tekstu, obraz kategorii narracyjnych) przekonują, że utwór jest bardziej opowieścią względnie mikropowieścią; tekst właściwy poprzedzony klauzulą wyłączającą „Tento príbeh sa nestane. Postavy a reálie nebudú mat' nič spoločné so skutočnost'ou a ich zhoda bude čisto náhodná”; rzeczownik w tytule záhrady (ogrody) podany wielką literą, $\mathrm{w}$ tekście bieżącym pisany przemiennie wielką i małą, z przewagą małej; to właśnie było przyczyną, że w opracowaniach dotyczących utworu w tytule podawany jest niekiedy literą małą.

Utwór rozpoczyna monolog wewnętrzny bohatera, Dušana Naturela (imię i nazwisko znaczące dla wymowy utworu i jego interpretacji), w którym prowadzi fikcyjne dialogi: jeden z koleżanką z pracy (Irmą) Valovą, późniejszą bliską przyjaciółką, oraz matką. Protagonista to pracownik naukowy, na ten dzień, jak na każdy inny, ma ściśle opracowany harmonogram zadań do wykonania. Będąc już w laboratorium zastanawia go nienaturalne zachowanie współpracowników; przypomina sobie, że dziś, 12 maja (rok nieokreślony), obchodzi 40. urodziny. Przełożony, Rárus, oraz cały zespół składa mu życzenia, przekazując mu wraz ze złotym medalem za zasługi standardową decyzję o obowiązkowej emeryturze. W nowoczesnym świecie każdy pracownik wieku 40 lat kierowany jest bowiem do „Záhrad” („Ogrodów”; rodzaju ośrodka dla starszych ludzi), gdzie korzystają z dobrodziejstw emerytury. Aczkolwiek zdruzgotany, bowiem w pełni sił zawodowych, przyjmuje do wiadomości zaistniałą sytuację i wynikające z niej konsekwencje. Jako że przez 25 lat pracy w instytucie ani razu nie skorzystał z prawa do urlopu, składa wniosek o jego przyznanie. Wybraną destynacją będzie odległy Cypr, gdzie mieli prawo odpoczywać jedynie najwyżsi rangą i osiągnięciami pracownicy; planuje, że na wyspie Afrodyty spędzi resztę życia. Będąc już w samolocie, ze zdziwieniem stwierdza, że współpasażerami lotu są jego koledzy z instytutu, wśród nich Irma i Michal (najbliższy przyjaciel). Czas urlopu to czas beztroski, między Naturelem a Irmą rodzi się uczucie. Jednego dnia Naturel udaje się do cypryjskich Záhrad, które tutejsi nazywają Rodiskiem; zafascynowany tym miejscem składa wniosek o możliwość spędzenia tu emerytury, okazuje się jednak, że jest to niemożliwe. Będąc przypadkowo świadkiem pogrzebu, dowiaduje się, co potwierdza w bibliotece, że ciała zmarłych utylizowane są na Cyprze przez mrówki. Po powrocie do domu jest bohaterem konwencjonalnej uroczystości przyjęcia do wspólnoty Záhrad. Upływają dni, przyzwyczajony do zaplanowanego rytmu dnia pracownika naukowego zwyczajnie się nudzi; stan ten przerywa spotkanie z Róbertem Grafem, projektantem kompleksu, odtąd staną się niemal nierozłączni. Do mieszkania dociera, wraz z niespodzianką - Irmą - w środku, zapomniana przezeń na Cyprze walizka; przez dłuższy czas Naturel korzysta z uroków życia domowego. Odwiedza również Grafa, który pokazuje mu plany alternatywnego ośrodka, gdzie człowiek, naturalnie pod ścisłą kontrolą i reżyserią, będzie się musiał troszczyć sam o sobie; jako kandydata do przeprowadzenia takiej próby widzi właśnie Naturela. 
Ten zgadza się; razem z nim na przygodę wyrusza Irma. Zaczynają żyć jak przodkowie, w ścisłym kontakcie z przyrodą; o ile Naturel szybko uczy się życia łowcy, o tyle Irma, prezentująca kulturę cywilizacji, pozostaje wstrzemięźliwa. W trakcie jednej z wędrówek, Naturel znajduje zaatakowaną przez czarne mrówki, konającą żabę. Wedle informacji, w areale, chronionym chemiczną ochroną, mrówki nie powinny występować; śledząc ich ścieżki, dochodzi do krańca areału; decyduje się wykonać decydujący krok - opuszcza granice areału i odnajduje mrowisko. Obserwując życie mrówek, ich agresję oraz bezwzględność, dochodzi do wniosku, że ew. wojna ludzi ze zwierzętami (tu: mrówkami) jest jak najbardziej możliwa. Będąc z powrotem w chacie, naciska przycisk niebezpieczeństwa; przed odlotem zabiera jednak potajemnie kilka mrówek, by w Záhradach prowadzić nad nimi badania. Upływa kilka miesięcy. Naturel poznaje Jakubca oraz kierowaną przezeń sekretną bibliotekę, z której wypożycza kilka książek nt. mrówek; hodowla ma się dobrze, mrówki się rozmnażają. Zaniedbywana przez cały ten czas Irma, w trakcie jednej ze sprzeczek zdradza, że wie o istnieniu tajemnego laboratorium, co więcej zafascynowana mrówkami obserwuje je i dokarmia; od tego czasu o mrówki dbają oboje. Z nielegalnej wyprawy poza chronione murem granice Záhrad Naturel przynosi do hodowli inny gatunek mrówek, czerwonych. Pomiędzy czarnymi i czerwonymi mrówkami wybucha konflikt, obserwując zmagania Naturel przeczuwa, że zwycięzcą zostałyby mrówki czerwone. Pogrążona w kryzysie Irma decyduje się na doniesienie władzom o nielegalnej hodowli, czemu w ostatniej chwili udaje się Naturelowi zapobiec. Na propozycję Grafa udają się wraz z nim za granice areału, gdzie są świadkami pogrzebu; ciało zmarłego zrzucone zostaje z muru granicznego na pożarcie mrówkom; przygotowana potajemnie do wykonania tego kroku Irma wypija truciznę, umiera i stacza się w mrowisko. Śmierć Imry odbija się na psychice bohatera; ze stanu depresji pomaga mu wydostać się Graf; pojawia się również młodziutka Sonia (Soňa), z którą Naturel nawiązuje romans. W trakcie jednej z wizyt w domu starców Naturel słyszy opowiadaną przez staruszkę bajkę o królewiczu L’ubomírze, jego niewiernej wybrance Dorce i najlepszym przyjacielu Mateju; w przekazie pojawiają się również mrówki. Naturel i Sonia układają sobie życie; na 50. urodziny odwiedza go szef dawnego instytutu, Červeňák - z zachowania i wyglądu niemal wierna kopia Rárusa. Sonia od dłuższego czasu przygotowuje się do poważnej wyprawy, pragnie spotkać ukrywających się za murem „niecywilizowanych”; wspólnie przechodzą na drugą stronę ukrytymi w murze drzwiami. Nieprzyzwyczajeni do niesterylnych warunków, oboje przeżywają ciężkie chwile; na skraju wyczerpania odnajdują prymitywne siedlisko (tabor) „niecywilizowanych”; Naturel zapada na ciężką chorobę. Wśród mieszkańców taboru Sonia czuje się jak u siebie; odnajduje tu kilku atrakcyjnych mężczyzn - Naturel jest w wiosce najstarszy, w jednym z nich się zakochuje. Bohater wychodzi z choroby, włącza się w rytm życia taboru, odkrywając, że samodzielność jego mieszkańców jest jedynie pozorna: wszystko, czego potrzebują do „niecywilizowanego” istnienia, dostają z Záhrad; społ. „niecywilizowanych” okazuje się bowiem być kolejnym projektem alternatywnego sposobu życia zdającego sobie sprawę z zagrożenia, jakie dla ludzkości niesie sama instytucja Ogrodów, Grafa. Naturel powraca do Záhrad. Przypomina sobie o mrówkach, w trakcie wizyty w laboratorium stwierdza, że owady przeżyły długi okres jego nieobecności; w pewnym momencie Naturelowi zdaje się, że nawiązał $\mathrm{z}$ mrówkami kontakt i sam zamienił się w jedną $\mathrm{z}$ nich, to umożliwiło mu poznanie praw rządzących wśród mrówek i ich możliwe cele. W instytucie badań nad owadami zgłasza informację o realnym zagrożeniu, jakie przedstawiają dla ludz- 
kości mrówki, okazuje się jednak, że niebezpieczeństwo to jest doskonale znane. Naturel decyduje się działać na własną rękę, wraca do Záhrad i w różny sposób ostrzega ich mieszkańców przed mrówkami. Pochwycony jako psychicznie chory, wywieziony poza ich teren, uzyskuje prawo do jednorazowych odwiedzin w Záhradach; udaje się do Grafa, którego znajduje nieżywego z nożem w plecach, na jego ciele znajdują się włosy Naturela oraz ślady po ukąszeniach mrówek; zostaje oskarżony o zabójstwo Grafa. Sanitariusze pozostawiają związanego Naturela przed jego domem; w międzyczasie ogłoszony zostaje alarm o skażeniu terenu; przedostają się informacje o inwazji mrówek na Záhrady, ich obozem jest mieszkanie Naturela. Już w karetce Naturel jest świadkiem akcji dezynfekcyjnej, w trakcie której jego dom zostaje zniszczony.

$V$ Záhradách jest trzecim w kolejności utworem VÁŠOVEJ w konwencji SF; w jej twórczości zależność między gatunkiem p. a konwencją SF jest charakterystyczna, jako że żaden z jej wcześniejszych i późniejszych utworów prozatorskich nie jest p. Podobnie jak $\rightarrow$ Po, choć w mniejszej mierze, stanowi utwór synkretyczny, jeśli chodzi o jego implikowanego odbiorcę: tekst może być uznawany zarówno za utwór dla dorosłych, jak i dla nieco starszej młodzieży; w tym aspekcie odróżnia się od uznawanego za najlepsze jej osiągnięcie 7,5 stupňa Celzia (1984, oraz wcześniejszego utworu Bliženci z Gemini (1981, przeznaczonych jednoznacznie do czytelnika młodzieżowego; Ukierunkowanie $\rightarrow P o$ oraz $V$ Záhra-dách także na młodszego czytelnika było wynikiem specyfiki rozwoju słow. SF, która zasadniczo i we wszystkich swych etapach rozwojowych realizowała się najpełniej w uznawanym wówczas za marginalny obiegu lit. dziecięcej i młodzieżowej; 1. 70. i przełom dekad to dodatkowo w lit. słow. czas tzw. normalizacji, kiedy to w wyniku powrotu do poetyki realizmu i służebnych względem ideologii zadań lit. konwencja SF znalazła się niemal wyłącznie w obrębie lit. dla młodszego czytelnika; praktycznie jedyną słow. p. SF dla dorosłego czytelnika w pierwszym pięcioleciu siódmej dekady XX w. był utwór $\rightarrow C u$ dzie svety I. IZAKOVIČA. Utwory $\rightarrow$ Po, Bliženci z Gemini, V Záhradách, 7,5 stupňa Celzia tworzą zwarty i odmienny konwencjonalnie etap w twórczości prozatorskiej autorki, wcześniejsze i późniejsze próby to proza dnia powszedniego, „małych historii”, obrazków z życia; na przełomie 1. 70. i 80. dekady XX w. VÁŠOVÁ była tym z pisarzy, który w najkonsekwentniejszy sposób propagował konwencje SF w lit. słow.

W utworze pojawia się wiele planów znaczeniowych, pozostających między sobą w różnym stopniu zależności. To wręcz dzieło o charakterze palimpsestu (P. ZAJAC), które trudno odczytać bez znajomości europejskich kodów kulturowych, także literackich.

Przede wszystkim odnajdziemy tu kolejną próbę odpowiedzi na właściwe dla niemal całości twórczości VÁŠOVEJ pytanie o system wartości człowieka/ludzkości, o sens jego istnienia, o możliwość jego utrzymania w warunkach skrajnie niekorzystnych. W utworze $V$ Záhradách problem ten realizuje autorka przy pomocy schematu fabularnego opartego o zagrożenie degradacją wartości, funkcji i znaczenia człowieka/ludzkości w świecie, w którym wszystko ukierunkowane zostało na to, by mu/jej jak najbardziej ułatwiać życie („Záhrady nespája nič so svetom a starostami [...], všade sama prevencia a hygiena! Každý bacil pod kontrolou!").

W aspekcie poetyki SF $V$ Záhradách to przykład pierwszej w słow. SF antyutopii, jako że kreowany przez autorkę obraz świata w przyszłości nie jest obrazem progresywnym względem punktu wyjścia; jednocześnie to kolejny po $\rightarrow$ Po przykład wizji przyszłego świata, który do znanego nam będzie jedynie podobny. 
Stosunek człowieka i przyrody generuje kolejny plan znaczeniowy utworu, przy czym VÁŠOVÁ wpisuje się tu w szerszy proces, bowiem na początku 1. 80. zaznaczają się w lit. (m.in. A. BALÁŽ, $\rightarrow$ Skleníková Venuša; L. JURIK, $\rightarrow$ Novinári) i kulturze słow. silne tendencje proekologiczne, które w 1988 kulminować będą w ruchu skupionym wokół publikacji „Bratislava/nahlas”. Tytułowe Ogrody powstały również po to, by chronić ludzkość przed zagrożeniami, jakie stanowić może przyroda; trzymanie roślin jest w ośrodku ściśle kontrolowane (,je to správne, nekontrolované množenie zelene by mohlo... Možno by zmenilo celý svet na rezerváciu”), zwierzęta są w Záhradach nieobecne; ich mieszkańcy i - jak można domniemywać - wielka część „,cywilizowanej” ludzkości w czasie fabularnym utworu przyrody się obawia. Jak pozorny wyjątek funkcjonują tu „niecywilizowani” z obozowiska poza ośrodkiem oraz całkiem oczywiście Naturel, o czym zaświadcza już samo nazwisko (,znaczy” także jego imię - Dušan, wywodzące się od duszy), w dzieciństwie zwierzęta go fascynowały, zawodowo prowadził badania nad myszami, nielegalnie hodował mrówki. Te zaś przedstawione są w utworze jako zagrożenie zdolne do eksterminacji ludzkości w każdym momencie. Niełatwo się ich pozbyć, to organizmy odporne i zahartowane, zdolne do przeżycia w środowisku niemal całkowicie wyjałowionym. Krytyka (M. MIKULOVÁ) skłaniała się ku interpretacji, że mrówki to zemsta przyrody na człowieku, zauważyć wszakże należy, że mrówki są jednak pasywne, wykonują jedynie zadania, które przydzielili im ludzie. Motyw utylizacji ciał zmarłych ma silne nasycenie symboliczne, zmarły człowiek wraca w ten sposób do przyrody, staje się częścią naturalnego cyklu - nierozerwalnego związku człowieka z przyrodą, który poprzez izolację ludzkości starano się przerwać; tak właśnie interpretować można akt samobójstwa Irmy.

Obie p., $\rightarrow$ Po i $V$ Záhradách, wiąże motyw początku ludzkości, przy czym w drugiej został on zredukowany, gubi się w natłoku innych tematów. W odróżnieniu od pierwszej, w której demiurgiem jest robot-konstruktor, w tu omawianej człowiek w sposób sztuczny odtwarza pierwotny świat ludzkości.

W tle głównych zdarzeń fabularnych ukazuje VÁŠOVÁ konflikt jednostki i społ. Naturel powszechnie uznawany jest za dziwaka, zarówno przez „cywilizowaną” część ludzkości, jak i tę, jedynie pozornie, „niecywilizowaną”. Od małego był samotnikiem, takim też pozostał przez okres pracy zawodowej, nie potrafi się odnaleźć również w Ogrodach. Niezrozumienie społ. dla odmienności, inności prezentowanej przez Naturela przejawia się m.in. w uznaniu go za psychicznie chorego i odizolowaniu od już odizolowanego społ. mieszkańców Záhrad. Pole problemowe niemożności porozumienia, izolacji, konfliktu na linii jednostka-społ. wychodzi, przynajmniej po części, z faktu, iż VÁŠOVÁ, podobnie jak reszta przedstawicieli „Mladej tvorby”, należała do pierwszej generacji słow. autorów, która dorastała w lub przesiedliła się do aglomeracji; stąd wynikała ich wrażliwość na te kwestie.

Izolacja jako zjawisko socjalne wyróżnia się spośród innych wątków. W utworze łatwo prześledzić różne jej sposoby, izolowane są jednostki (Naturel, częściowo Jakubec), określone grupy ludzkości (emeryci z Záhrad od społ. aktywnych zawodowo, „niecywilizowani” od „cywilizowanych”), członkowie rodziny od innych członków (Naturel praktycznie nie widuje się z matką i rodzeństwem), cała ludzkość izoluje się od wpływów zewn., przede wszystkim od przyrody, tworząc różnego rodzaju przestrzenie zamknięte, jak tytułowe Ogrody.

Uwagę zwraca rozwój wewn. Naturela. Przypada on przede wszystkim na pobyt w Ogrodach, wcześniej funkcjonował jako jeden z trybów społ. Wrażliwość społeczna, 
potrzeba przemyśleń nad podwalinami ludzkiej egzystencji, podstawowe uczucia (miłość) budzą się w nim dopiero „na emeryturze”, dopiero wówczas staje się w pełni Dušanem. Również najważniejszy projekt zawodowy przypadł na czas odpoczynku: na emeryturze podjął wyzwanie badawcze, które mogło mieć znaczenie dla całej ludzkości. Naturel w ostatecznym rozrachunku ponosi jednak porażki: nie udało mu się ożywić Ogrodów i, jak się zdaje - również ochronić ludzkości, alternatywny względem Ogrodu-raju niepotrzebnych ludzi raj serca, czyli miłość do Irmy, także kończy się tragedią.

Przestrzennym tytułem oraz lejtmotywem nawiązała VÁŠOVÁ do prastarego motywu ogrodu, sięgającego tradycją w światowej lit. i sztuce od perskiej pairadaeza, wyobrażeń Mezopotamii, antycznych Ogrodów Hesperyd, biblijnego ogrodu Eden, wczesnochrześcijańskich konstrukcji, Ogrodu rozkoszy ziemskich H. BOSCHA, przez wyobrażenia bardziej nowoczesne: barokowe, romantyczne. W sposób oczywisty powiązany został z semiosferą raju, przede wszystkim Rajskiego Ogrodu jako wydzielonej i ogrodzonej części arkadii. W zwyczajowej wykładni raj to miejsce, skąd pochodzimy, ale i dokąd chcemy podążyć/ wrócić, przy czym autorka dokonuje tu gorzkiego przewartościowania. Abstrahując od faktu, że Naturel wcale nie pragnie udać się do Rajskiego Ogrodu, ten nie jest w realizacji autorki miejscem szczęśliwości. Oznacza bowiem zamknięcie, izolację, nieprzydatność; Záhrady odgrodzone są wysokim murem, co, z uwagi na uzasadnioną możliwość odczytu p. jako antytotalitarnej (por. dalej), nawiązywać może również do muru berlińskiego oraz Żelaznej Kurtyny oddzielającej Wschód od Zachodu; Ogród-raj nie prezentuje się w najmniejszym nawet stopniu jako wyczekiwana wspólnota konwiwialna. Najważniejszym osiągnięciem VÁŠOVEJ w zakresie transformacji motywu Rajskiego Ogrodu było jednak jego umiejętne powiązanie z konwencją SF, w rezultacie czego otrzymaliśmy interesująca antyutopię o wymiarze antytechnicznym. Próba zamiany bohatera w mrówkę jest oczywistym nawiązaniem do Przemiany (1912) F. KAFKI.

$V$ Záhradách to mikropowieść obywająca się w aspekcie architektoniki bez limitacji, tekst jest ciągły, bez podziału na rozdziały. Sposób narracji specyficzny, utwór rozpoczyna monolog wewn. protagonisty, od s. 17 przechodzi w klasyczne epickie praeteritum (3 sg., czas przeszły); monolog wewn. bohatera i innych postaci pojawia się jednak często w dalszych partiach tekstu; do monologów wewn. często wprowadzane są bezpośrednie wypowiedzi innych postaci oraz dialogi (np. z Irmą, z matką). Dla utworu właściwa jest wysoka frekwencja dialogów bez funkcji fabułotwórczej i informacyjnej, podporządkowanych relacji narratora, często uproszczonych; na s. 123-127 wtrącony gatunek bajki bez większej funkcjonalności dla fabuły i interpretacji. Przebieg fabularny podlega akceleracji w miarę zbliżania się do końca.

$V$ Záhradách jest tym utworem SF autorstwa VÁŠOVEJ, względem którego i krytyk, i baczny czytelnik, wnieść może najwięcej zastrzeżeń. Wielość i różnorodność tematów i wątków, które z uwagi na ograniczony rozmiar, nie mogły w utworze zostać wyczerpująco opracowane, sprawia wrażenie niedopracowanych właśnie, niekiedy niespójnych.

Uprawnione są próby odczytywanie utworu w optyce antyreżimowej. Tytułowe Záhrady, odizolowane od zagrożeń, w których wszystko funkcjonuje bez przeszkód, idealnie, a jednak zawsze pod kontrolą, młodzi emeryci, którzy po owocnym etapie życia zawodowego przeznaczonego dla kolektywu odpoczywają w luksusowych warunkach - jako żywo przypominają obiecywany przez reżim stan socjalistycznej szczęśliwości. Czas powstania utworu to w warunkach słow. doba tzw. reálkomunizmu, w którym władze doszły do (uza- 
sadnionego) przekonania, iż by zneutralizować przeciwników ideologicznych nie trzeba ich wcale osadzać w więzieniach, wystarczy jedynie odciąć ich od społ., od pracy - w ten sposób stawali się bezużyteczni. Podane w powyższym skrócie fabuły konkretne wydarzenia i sytuacje nietrudno zdeszyfrować jako (niespecjalnie) skrywaną alegorię sposobu funkcjonowania reżimu i społ. socjalistycznego. Podkreśla to również pojawiający się w warstwie narracyjnej (głosu narratora i postaci) pastisz socjalistycznej nowomowy (np. przemowa Rárusa z okazji urodzin Naturela). Zarówno w p. $\rightarrow$ Po, jak i w tu rozpatrywanej, nieludzkie, odpowiednio robocie lub zwierzęce, środowisko służy krytyce, demaskowaniu systemu totalitarnego i sposobów jego funkcjonowania.

Lit. J. Puškáš, Obraz mučivého raja, „Nové slovo” 24, 1982, nr 23; M. Mikulová, Alta Vášová: V záhradách, „Slovenské pohl'ady” 99, 1983, nr 1; P. Zajac, Raj sveta, labyrint srdca, „Romboid” 39, 2004, nr 9; J. Štrasser, A. Vášová, Sledoslov: rozhovory s Altou Vášovou, Bratislava 2015.

TOMASZ DERLATKA

On the Guidebook to the Novels of the West Slavs (1945-1995)

\section{Summary}

This article contains a selection of notions from the Guidebook to the Novels of the West Slavs (a working title). The Guidebook is addressed predominantly at researchers involved in comparative studies of the literatures of the West Slavs and it will cover fifty years (1945-1995) of novels written by West Slavic authors: Kashubian, Polish, Slovak (from Slovakia and the so-called Lower Land), Czech as well as Upper and Lower Lusatian, and how they changed. Each entry will consist of a brief presentation of a novel's content, bibliographical information (the subsequent editions, possible translations; reception in the other languages will be limited exclusively to the West Slavs area), interpretation, a novel's significance to a writer's achievements, specific national literature and, finally, the West Slavs' novels as a whole, a selection (maximum five items) of the most important literature on the subject.

Keywords: novel, literature of the West Slavs, comparative studies 